\title{
TRADING OUT OF THE GLOBAL FOOD CRISIS? THE WORLD TRADE ORGANIZATION AND THE GEOPOLITICS OF FOOD SECURITY
}

\author{
Matias E. Margulis* \\ Division of History and Politics \\ University of Stirling \\ Email:.m.e.margulis@stir.ac.uk
}

\begin{abstract}
:
The geopolitics of the Global Food Crisis and international trade has received limited scholarly attention, a significant omission given the major roles of the World Trade Organization (WTO) in structuring world food production and trade flows and as a principal inter-state governing mechanism of the global agro-food system. Analysing recent international policy actions framing the WTO as a 'fix' to the Global Food Crisis, this article points to the value of a critical geopolitics of agro-power sensitive to the spatial reconfiguration of production and power in the global agro-food system, problematizing geospatial categories such as 'North' and 'South', and that takes seriously contests for control of geopolitical agents such as the WTO.
\end{abstract}

*This is an Accepted Manuscript of an article published in Geopolitics 19(2): 322-350 (2014), available at: http://www.tandfonline.com/doi/abs/10.1080/14650045.2014.920233 


\section{INTRODUCTION}

The 2008 Global Food Crisis and subsequent food price spikes are potent reminders of the enduring unpredictability and instability of the global agro-food system. Few analysts foresaw the crisis and fewer could have imagined the extent and duration of its consequences. High and volatile prices have disrupted global food flows and made concerns about access and supply of food preeminent in national and international policymaking. Widening asymmetries of producer power are evident in the inability of small-scale producers to benefit from higher prices; meanwhile transnational agro-food corporations enjoy record profits. ${ }^{1}$ Whereas the recent data suggests the crisis was slightly less severe than initially estimated, heightened levels of human deprivation and indignity remain a global concern given how unevenly the crisis's effects were distributed, particularly across the African continent where the number of undernourished increased in absolute terms by twenty per cent. ${ }^{2}$ Unlike the World Food Crisis of 1974, where food prices quickly returned to pre-crisis levels after a couple of years, food prices remain above pre-crisis levels, thus pointing to a historical disjuncture from the longer-term decline of food prices (see Figure 1). ${ }^{3}$ This disjuncture is commonly referred to as "the end of cheap food". The durability of the present crisis, now running over five years and having erased much of the gains made in reducing world food insecurity over the past two decades, explains why food security remains high on the global policy agenda (unlike the 1974 crisis when political will to address world food insecurity quickly dissipated). ${ }^{4}$

Figure 1. FAO Food Price Index in real terms, 1961-2010

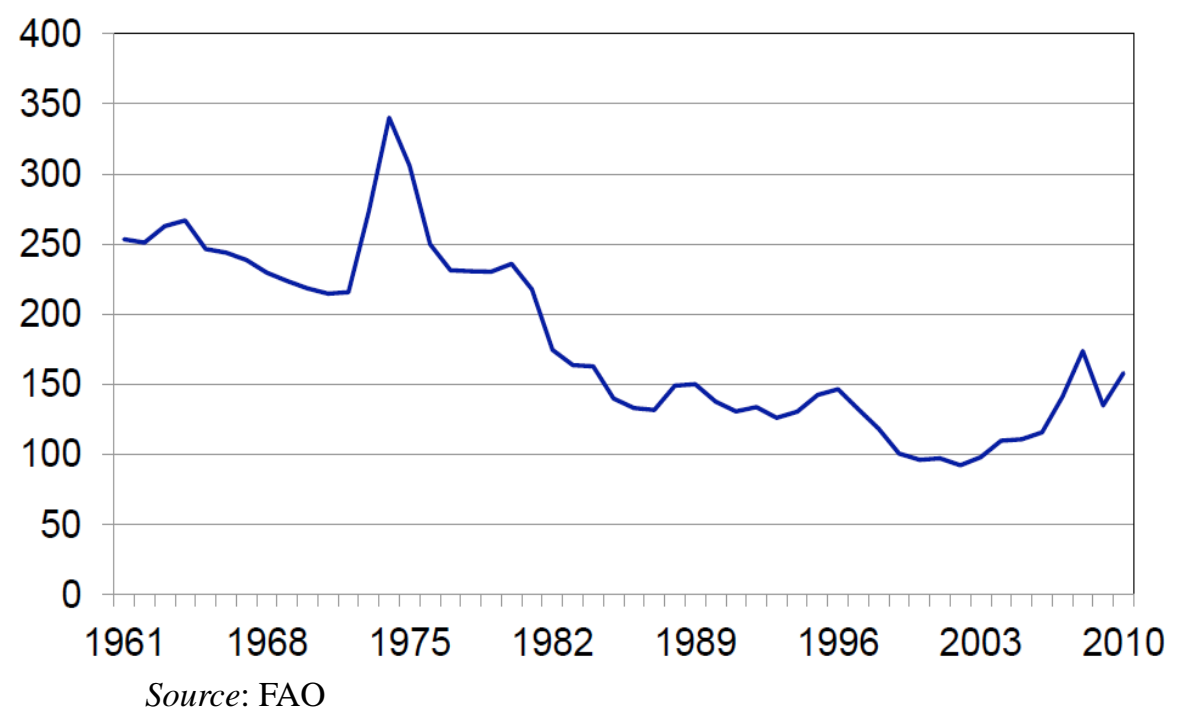

The end of cheap food is regularly discussed in terms of the crisis' highly unequal effects on the capacity of individuals and households to access food. Yet an event such as the food crisis brings into sharp relief that much world hunger is not the inevitable outcome of natural phenomena but a form of geopolitical violence socially constructed through power relations. ${ }^{5} \mathrm{An}$ important yet overlooked dimension of the food crisis and the end of cheap food is their influence on inter-state relations, and thus geopolitics. Recall that declining food prices was the distinguishing characteristic of the post-war global food order. ${ }^{6}$ Cheap food was the outcome of a particular geopolitics and geoeconomy of food, one where mounting agricultural structural surpluses in the North were accommodated by a mix of Southern food import dependency and an 
international food aid regime. ${ }^{7}$ This geoeconomics of food resulted from, and reproduced, a specific set of geopolitical relations that permitted, for example, the use of food by the United States (US) as an instrument of foreign policy ambitions in facilitating the reconstruction of postwar Europe and selective parts of Asia. ${ }^{8}$ Later transformations of the geopolitical food order, including the restructuring of agriculture in the developing world towards non-food commodity exports in the 1970s/1980s followed by increasing corporate control of the global agro-food system in the 1990s and onwards, can be understood as historical outcomes consistent with the political economy conditions of cheap food. ${ }^{9}$

Power relations within geopolitical food orders require a set of institutional architectures to legitimize and facilitate them. Trade rules under the embedded liberalism of the General Agreement on Tariffs and Trade (GATT) and its neoliberal successor, the World Trade Organization (WTO), are such architectures. ${ }^{10}$ The Global Food Crisis occurred during a historical moment of intense geopolitical conflict at the WTO. It is not insignificant that since the crisis states have taken a multitude of actions that diverge from the WTO's mission of freer trade in food; these actions include food export restrictions, national food self-sufficiency policies, efforts to regulate agricultural derivatives, and the acquisition of farmland abroad. ${ }^{11}$ Such actions illustrate that states are experimenting with alternatives to international trade to achieve national food security. ${ }^{12}$ Yet the question of how the Global Food Crisis may be altering the geopolitics of food security and the international trade system has received limited attention by political geographers. ${ }^{13}$ This is a significant omission given the WTO's role as the principal inter-state forum for international and domestic food policy and in structuring global food relations, production and flows. This article argues for the value of a critical geopolitics analysis of interstate contests over food security at the WTO. The article is organized as follows. The first section outlines a framework for analysis for a critical geopolitics of agro-power at the WTO taking into account the shift towards a polycentric global agro-food system, problematizing the frame of North-South conflict, and taking seriously inter-state conflicts for control of institutions such as the WTO. The second section historically situates the international trade system in the geopolitics of food security. A third section analyses the recent geopolitics of food security at the WTO, including discourses framing the WTO as a solution to the crisis and contests over food security-related trade provisions, the negotiating of new food security-related trade provisions and the regulation of food export restrictions.

\section{A CRITICAL GEOPOLITICS OF AGRO-POWER}

This section develops three theoretical propositions informed by a critical geopolitics approach and the wider scholarship on power in the global system. This article is primarily interested in analysing inter-state power relations and thus takes states as the central unit of analysis. Also considered are international organizations, which are both arenas for inter-state politics and actors with their own interests. Private actors and global civil society are not directly analysed here. ${ }^{14}$ Such actors, while important for the study of the global food system in general, are not crucial to the study of geopolitics of food security at the WTO. This paper in particular cautions against uncritically "reading in" private power into the geopolitics of food security at the WTO. The scholarly literature on the WTO points to complex negotiating dynamic on agricultural trade issues where the interests of agro-food corporations are not preeminent. ${ }^{15}$ Thus agriculture at the WTO is distinct from other trade issues at the WTO, such as intellectual property rights and trade in services, where scholarship confirms corporations were central players in agenda-setting and 
drafting trade rules. ${ }^{16}$ The transnational food sovereignty movement, which emerged in opposition to the WTO, is active at the United Nations (UN) but refuses on principle to engage with the WTO. ${ }^{17}$ Development, social justice and environmental non-governmental organizations (NGOs) continue to press for fairer trade policies at the WTO through their advocacy, capacitybuilding activities and lobbying of member states and the WTO secretariat. Yet NGOs remain outside the corridors of power at the WTO and have limited influence on the outcomes of interstate negotiations. ${ }^{18}$

The approach adopted in this article takes seriously John Agnew's warning about reifying the state, as well as similar methodological concerns noted by scholars of the internationalization of the state. ${ }^{19}$ There are practical reasons for a state-focused approach to the study of the WTO because this institution features an idiosyncratic negotiating structure that reinforces traditional inter-state power relations by encouraging, for example, coalition-building and small group bargaining dynamics, and deepening international-domestic political linkages (what Robert Putnam called 'two-level games'). ${ }^{20}$ Other considerations are the unique historical trajectory of agriculture and food in the international trade system, including the specificity of food trade policy under the WTO's remit that institutionalizes and reinforces states preference to retain scope for intervention in agricultural markets. ${ }^{21}$ Future research should aim for greater synthesis of the ways state, private and other forms of power play out and interact in the global agro-food system; however, the task of this article is confined to the elucidation of inter-state dynamics.

I now turn to introducing the three theoretical propositions informed by a critical geopolitics of the global agro-food system. The first proposition is that a critical geopolitics approach renders more visible the spatial reconfiguration of production and power in the global agro-food system, and their representation in global food politics. Historically, the study of global food politics has taken US political hegemony and the market dominance of Northern agro-business as a central feature of a globalizing agro-food system. ${ }^{22}$ However, the Global Food Crisis is occurred during a period of transition away from a Northern dominated international food regime towards a polycentric one. ${ }^{23}$ Global food production today is no longer dominated by the Northern grain producing nations of the US, European Union (EU), Canada, and Australia. Southern agro-food powerhouses such as Brazil, Thailand, Vietnam and Argentina make up an increasing and major share of world agricultural production, trade and consumption. Moreover, many of these countries compete directly (and successfully) with the US and other Northern states in third country markets for temperate products such as wheat and soybeans. Another important and related development is that Southern countries are major producer of 'flex crops'; these are crops that have multiple food and fuel uses (e.g., palm oil, soybeans, sugarcane, maize, etc.) and are critical to the emerging global biofuel complex and political economy of the 'green economy' (See Figure 2). 
Figure 2: Brazil, India, Russia and China's share in selected flex crop production, world total (\%)

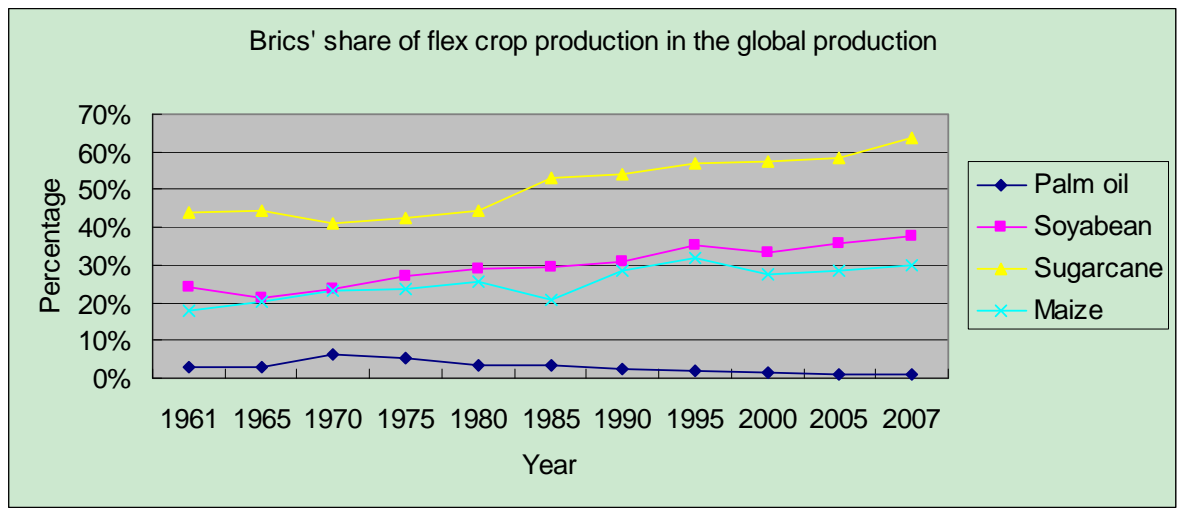

Source: Borras, Franco and Wang (2012); FAO

The spatial reconfiguration of food production and trade flows is accompanied by a corresponding geopolitical shift in agro-power observable along multiple fronts of global food and agriculture governance. ${ }^{24}$ During the current Doha Development Round (DDA) of WTO agriculture negotiations a group of emerging countries led by Brazil, China and India are successfully challenging the dominance of the US and EU. Another example is the newly created agriculture ministers grouping at the Group of Twenty (G20) that sets global policy priorities on agriculture reform and food security issues. ${ }^{25}$ Parallel to these political developments, the expansion of agro-food corporations from emerging states confirms private agro-power is too becoming polycentric. ${ }^{26}$ Take the Brazilian-based firms JBS and Brazil Foods that rank at the top of global market share for meat and grains, and are consolidating their positions through direct acquisitions of agro-food interests in the North. ${ }^{27}$ Abu Dhabi recently created a food-trading firm to compete with Cargill and Archer Daniels Midland. ${ }^{28}$ Chinese-firm Shuanghui is purchasing US-based Smithfield Foods, the world's largest pork producer. Not only is the transnational reach of corporations from emerging states rapidly expanding; such expansion blurs the publicprivate divide. In many emerging states, government and firms work closely together and in some cases there is direct state support (i.e., export promotion, financing, commercial diplomacy, etc.) for national agro-food firms to expand abroad. ${ }^{29}$ The transition towards a polycentric global agro-food system is underway where traditional Northern states and agro-food firms no longer dominate as previously. In turn, the transition opens new geopolitical space to reconstitute agropower relations, including the modification of institutional architectures.

Second, a critical geopolitics of agro-power problematizes existing geospatial categories such as North and South through which struggles over the agro-food system are generally articulated. Global food studies have a tendency to regard North-South struggles as the most significant political fault-line, such as scholarship on agricultural structural adjustment in the global South. ${ }^{30}$ A North-South conflict frame has been powerful in explaining the past yet a shift towards a polycentric global agro-food system suggests that analysis of conflicts necessitates a multivalent approach. ${ }^{31}$ The point here is not that North-South categorizations are no longer relevant but that its uncritical use obscures new and different geopolitical tensions. Recent Chinese and Gulf States' land grabs in Africa for outsourced food production are articulations of 
new spatial dynamics of agro-power where "Southern" states seek greater economic and political control of food production, distribution and consumption abroad. ${ }^{32}$ The shift towards polycentrism and the accompanying multidirectional flows of agro-power require new/refined analytical categories to capture the changing spatiality of power. Meta-concepts such as geoeconomics are helpful for understanding changing relations between the geography of economy in the global agro-food system or approaches that situate transnational contests for control over global resources and governance institutions as interrelated processes. ${ }^{33}$

This article employs the categorization of net-food exporting (NFEs) and net-food importing (NFIs) states for the purpose of analysing multidirectional power flows at the WTO. There is no consensus definition for these categories, nevertheless they offer a useful organizing frame to analyse the geopolitics of the global agro-food system, especially with regard to their value as a proxy for a state's relative vulnerability to food insecurity. ${ }^{34}$ In the case of NFIs, which purchase and import food from international markets for national food security, this group of states is most vulnerable to food price volatility and changes in global food availability. NFEs are sensitive to volatility and market trends but their vulnerability to food insecurity is far less affected since such states generally produce quantities of food surplus to domestic consumption. Imports are primarily for luxury foods (i.e., tropical fruit, cocoa, etc.). A practical reason for using NFIs and NFEs in geopolitical analysis is that states use these categories in their political discourse and negotiation strategies at the WTO (see below). Helen Hawthorne argues that group-making categories and discourse are crucial for understanding the geopolitics of international trade; the recognition of the category of Least Developed Countries (LDCs) at the WTO resulted in improved market access for these countries and enhanced their general treatment in trade relationships. ${ }^{35}$ The categories of NFIs and NFEs are fluid and thus can capture relative shifts in a state's agro-power/vulnerability to food insecurity over time. ${ }^{36}$ For example, since 2000 an additional fifteen states transitioned from NFEs to NFIs. ${ }^{37}$ Also, NFEs and NFIs do not fall neatly along North-South lines. Many NFIs are located in the global South, such as most Sub-Saharan African states, but also include middle-income countries (e.g., Gulf States, Korea) and advanced economies (e.g., Japan, Switzerland, Israel). NFEs are a highly diverse group that range from advanced economies (e.g., US, EU, Canada, Australia), "new” agro-powers (e.g., Brazil, Argentina, Thailand, Vietnam), and (re)emerging agro-powers (e.g., Russia, Ukraine, Kazakhstan). ${ }^{38}$ These categories make clear asymmetries of agro-power at the global level since the vast majority of the world's states are NFIs (See Table 1). As a consequence, to achieve food security NFIs depend on world markets and good political and trading relationships with agro-powers. ${ }^{39}$ The geopolitical/geoeconomic conditions faced by NFIs illustrate that territorial sovereignty, food production and food security rarely align in a corresponding manner. ${ }^{40}$

\section{Table 1. Net Exporters and Importers by International Food Trade}

\begin{tabular}{|l|l|l|l|}
\hline & \multicolumn{2}{|c|}{ No. of Countries in Raw Food Trade } \\
\hline Country Group & Net Exporter & Net Importer & Total \\
\hline Industrial Groups & 13 & 20 & 33 \\
\hline Middle Income, all & 36 & 69 & 105 \\
\hline Low-income, all & 16 & 42 & 58 \\
\hline World, Total & 65 & 131 & 196 \\
\hline
\end{tabular}

Source: Adopted from Ng and Askoy (2008); UN COMM Trade Statistics 
Third, a critical geopolitics of agro-power alerts us to the inter-sate contests over geopolitical agents to exert greater control in the governance of the global agro-food system. US hegemony is evident at the International Monetary Fund (IMF) and World Bank, where it enjoys the majority voting rights and final say on policy. ${ }^{41}$ However, there has been growing scholarly attention to the limits of US hegemony in international organizations, including the use of governance institutions to the detriment of US power and legitimacy. US withdrawal from the International Criminal Court in response to unfavourable legal decisions, the Landmine Ban Treaty (which the US refused to ratify) and landmark WTO legal decisions finding US cotton subsidies illegal illustrate that control of institutions is always contested. Following this, this article treats formal international organizations as geopolitical agents over which control is contested due to their central role in the maintenance or remaking of the geopolitics food order. ${ }^{42}$ The diffusion of agro-power in a polycentric global agro-food system suggests the need to take contests over geopolitical agents more seriously, in this case, the WTO. In the context of a polycentric global agro-food system, we should expect to see new and different inter-state conflicts in seeking to steer the WTO towards positions that confirm and enhance the agro-power of certain states, in particular that of NFEs that have (at least historically) disproportionately influenced outcomes in multilateral trade negotiations.

\section{PRE-CRISIS GEOPOLITICS OF FOOD SECURITY AT THE WTO}

The WTO may not be the first international organization that comes to mind when one speaks about the geopolitics and governance of food security compared to the Rome-based UN food agencies or even the World Bank. ${ }^{43}$ Yet the WTO and its predecessor regime, the GATT, are important for understanding the changing configurations of agro-power and inter-state struggles over the global agro-food system. The WTO is a geopolitical agent central to regulating international agriculture trade, domestic agriculture policy, and by extension, food security at the national, international and transnational levels. The GATT governed international trade between 1947 and 1994 but purposely excluded agriculture. This exclusion was due to US refusal to ratify the 1948 Havana Charter that would have shifted control of food policy to a proposed International Trade Organization. ${ }^{44}$ Instead, states agreed to a multilateral trade agreement, the GATT, that became the platform for successive rounds of tariff reductions on industrial goods. The exclusion of agriculture in the GATT accommodated US preferences and provided an institutional architecture facilitating a geopolitical food order that Harriet Friedmann labelled a wheat-based food regime, which embedded US agricultural exports and its firms in a privileged position in the post-war period. ${ }^{45}$ The wheat food regime made American food exports relatively cheap thereby permitting US agro-power, food import dependence and geopolitical clientalism to go hand and hand. An important point here is the GATT (by excluding agriculture) maintained an international division of food (in)security that was super-imposed upon natural topography by a geopolitical food order anchored in US agro-power. ${ }^{46}$ The GATT's history is consistent with a North-South conflict framing (but also North-North conflicts as well) as Southern states and other Northern NFEs repeatedly challenged the legitimacy and inequity of the geopolitical food order. Such challenges occurred primarily in multilateral trade negotiations as states sought to insert agriculture and food security concerns into the GATT system (also at the UN Conference on Trade and Development in the late 1960s to late 970s). States efforts to challenge the USanchored geopolitical food order and regulate agriculture at the international level failed most strikingly during the Kennedy Round (1964-1967) and Tokyo Round (1973-1979) of GATT 
negotiations in the face of US resistance. ${ }^{47}$

Yet the institutional architecture of the geopolitical food order changed dramatically in the 1980s during the Uruguay Round (1986-1994) of GATT. A key shift in the Uruguay Round was that the US and EU took the lead in seeking to insert agriculture into the GATT. By this time these states were fiscally exhausted in part by massive agricultural subsidy programs from a prolonged a transatlantic food trade war. ${ }^{48}$ Concurrent at this time was the US and EU's ideological turn towards neoliberalism that reset the tenor of economic policy in support of 'freeing' agricultural trade. The outcome of the Uruguay Round resulted in the inclusion of agriculture into the newly established WTO under a new agreement, the Agreement on Agriculture (AoA). The AoA was a trade deal on terms set by the US and EU, the dominant agropowers at the time. ${ }^{49}$ The AoA is significant because it internationalized agriculture trade and food policy through legally binding commitments on states with the objective of progressively reducing agricultural tariffs, set binding limit on national agricultural subsidies and initiated policy convergence across the global North and South towards a market-driven global agro-food regime. ${ }^{50}$ Food security issues fall under the scope of the AoA but clearly as subsidiary to the overarching goal of trade liberalization. The AoA included provisions that defined permissible national interventions for domestic food security (e.g., domestic food aid, agricultural extension programs, crop insurance) and also at the international level (e.g., international food aid, export credit financing, export restrictions). ${ }^{51}$ Trade friction among agro-powers and NFIs was considerable during the Uruguay Round. Japan and Korea's demand to limit the marketization of food import policies was defeated by aggressive negotiation strategies by NFEs (i.e., US, Australia, Canada, Argentina and Brazil). Southern NFIs were relatively more successful by working as a bargaining coalition and negotiated for a side-agreement with agro-powers for guarantees of food aid and food import financing in anticipation of higher food prices, an outcome widely expected upon implementation of the AoA. ${ }^{52}$ Negotiating food security at the GATT illustrates that whereas NFIs may have limited control over physical food production, they can seek to exert other forms of control over food through geopolitical agents, in this case, through rule-making at the GATT/WTO.

The current Doha Development Round (DDA) of trade negotiations, launched in 2001, is the most protracted round in the history of the GATT/WTO. The DDA has been deadlocked since July 2008 with inter-state disagreement on agriculture and food security issues a key reason. ${ }^{53}$ Analysts are still unsure if the agreement on a subset of trade issues at the 2013 Bali Ministerial Doha will be sufficient to break the impasse. The DDA has marked a notable shift in agro-power at the WTO with the success of a new developing country bargaining coalition, the Group of Twenty (Ag-G20) led by Brazil, India and China (but not the same as the G20 that replaced the G8), in blocking the US and EU and advancing their own trade agenda. ${ }^{54}$ The Ag-G20's substantial influence on the Doha Round is an important indicator of the transition towards a polycentric geopolitical food order. The Ag-G20 is notably producing new patterns of inter-state conflicts at the WTO. In the agricultural negotiations inter-state conflicts feature new discourses by the Ag-G20 for "development" and "equitable" distribution of the gains from trade. As Kristen Hopewell observes, these new discourses are strategically created and used by emerging agro-powers to demonize Northern agricultural subsidies to galvanize political support from the global South and to strengthen their own position in negotiating for deeper agricultural trade liberalization. $^{55}$

Already prior to the Global Food Crisis the geopolitical conflicts over food security were significant. The Ag-G20's targeting of US and EU “dumping” of subsidized agricultural goods is 
one issue that was of common interest to emerging NFEs and food insecure states. ${ }^{56}$ Rules on dumping are a well-known asymmetry in the AoA, that due to technical intricacies that will not be addressed here left the majority of developing country WTO members (except emerging NFEs) without safeguard policies to stop dumping at the border. ${ }^{57}$ Agricultural dumping is an issue where the Ag-G20 allied early with the Group of Thirty Three (G33) - a bargaining coalition of developing countries demanding agricultural safeguards and led by India - to successfully negotiate two new trade policy tools. These are the Special Safeguard Mechanism (SSM) and the Special Products provisions, with the former designed to permit developing countries to respond to dumping by raising agricultural tariffs above their current bound limits set out in the AoA once the DDA is completed. ${ }^{58}$ The rules of the SSM and Special Products make clear these policy tools can be invoked for reasons of national food security, in particular to protect poor and vulnerable small farmers. The technical details of how the SSM will operate are highly contentious and not yet agreed upon. ${ }^{59}$ From the outside looking in the SSM appears to be a Southern victory over the North. Yet a closer examination reveals that even within the Ag-G20 there is disagreement over the design of the SSM. Emerging agro-powers such as Argentina, Brazil and Thailand face dumping infrequently and thus favour a more limited version than what is proposed by the G33, a group of countries that contains many NFIs and are more frequently and adversely effected by dumping. Whereas diverging positions on the SSM is unlikely to break the Ag-G20-G33 alliance, it is a potent reminder of ever more fractured geopolitics at the WTO. Also visible prior to the crisis were geopolitical tensions between Southern agro-powers and NFIs. In the first phase of the DDA negotiations (2001-2004) NFIs persuaded WTO members to explore the creation of a food-import financing facility (FIFF) to assist NFIs experiencing temporary difficulties meeting the cost of food imports. Advanced technical work on the FIFF took place during those years with technical assistance from the UN Food and Agriculture Organization (FAO), World Bank and IMF. ${ }^{60}$ The FFIF proposal was dropped in 2004 in part due to rejection by established and emerging agro-powers.

There has been considerable debate about the consequences of a failed DDA for world food security. It has been argued that the WTO's continued deadlock might be preventing agricultural trade liberalization that could be unfavourable for NFIs, for example, to the degree a new AoA may produce reforms that further drive up food prices. ${ }^{61}$ Jennifer Clapp argues that the WTO deadlock has dissipated political momentum for progressive reform on food security and commodities trade vital to the development interests of most poor WTO members. ${ }^{62}$ Another reading is that a failed DDA means forestalling the institutionalizing of a neoliberal global food order; however, this would serve to reinforce existing power asymmetries in the global agro-food system rather than undermine them. ${ }^{63}$

\section{THE WTO AND THE GLOBAL FOOD CRISIS}

The causes and consequences of the Global Food Crisis are the subject of a considerable body of research across the social science disciplines and within policymaking circles. Knowledge production about the Global Food Crisis is intimately linked with discourses of justifying or challenging the geopolitical food order. ${ }^{64}$ Contending perspectives on the crisis inform real world inter-state contests for control over geopolitical agents as the latter are involved in knowledge production about the crisis while being tasked with implementing the 'solutions'. Two contending perspectives are especially relevant for contextualizing geopolitical struggles. A first perspective frames the causes of the Global Food Crisis as a scientific controversy, 
understanding it as a singular event to be explained by identifying its proximate causes and inferring from this the appropriate solutions. This perspective is most associated with academic and professional economists from (mostly US) universities and international organizations. ${ }^{65}$ This self-styled scientific controversy revolves around the problem of determining which one of the many oft-cited policy drivers and external events are the principal cause, and how best to employ econometric modelling to determine causal relationships among many possible factors. Within the (economic) debate internal to this perspective, the principal causal factors cited are US and EU agrofuel policies, rising oil prices and, to a slightly lesser extent, the depreciation of the US dollar. ${ }^{66}$ The changing appetites of consumers in emerging markets are accorded very minor explanatory power and so is financial speculation. A second perspective situates the Global Food Crisis as the outcome of longer-term, unresolved contradictions of the global agrofood system, and focuses on the crisis's broader socio-ecological consequences rather than merely its proximate causes. This structural approach involves a different configuration of knowledge producers of social scientists (however few economists), professional researchers and activists working on a range of food, development and social justice issues. This second reading of the crisis is heavily informed by dependency theory and food regime scholarship.

Accordingly, the crisis is understood as prefigured by historical processes of internationalization and restructuring of world agriculture. ${ }^{67}$ Whereas earlier agricultural restructuring is understood to have set the stage for the crisis, new dynamics such as the finacialization of food and emergence of a global agrofuel economy are situated as accelerating unequal global food relations (and changing relations between capital and nature more broadly) ${ }^{68}$ Consequently, the debate about the causes and consequences of the crisis can also be understood as expressions of agro-power (or the lack of it) because states (and non-state actors) have differentiated but very unequal resources and capacity to produce knowledge and truth claims about the crisis (i.e., to diagnosis the problem and to offer and promote solutions; or the basis upon which to decide which account of the crisis is more 'true' or policy option more 'effective'). Most important for the purposes of this article are the ways in which knowledge production and discourse continue to shape the debate about the role of international trade as a cause and solution to the crisis, and thus the role of the WTO.

\section{WTO to the rescue? Or Global Food Crisis to the rescue of the WTO?}

The DDA ground to a halt at the Geneva mini-ministerial just as the global community grasped the enormity of the Global Food Crisis. 2008 was a low point for the WTO with states public acknowledging their positions were too far apart for a likely agreement in the near future. Trade analysts expressed concerns that the WTO was not just "dysfunctional" but that the deadlock could render the WTO irrelevant as states shifted their attention away from multilateral trade negotiations to pursue bilateral and regional trade agreements. ${ }^{69}$ Global policy elites were quick to proclaim the WTO as a potential solution to the crisis, which offered a new diagnosis of the crisis. For instance, consider the G8's 2008 Statement on Global Food Security that declared:

Food security also requires a robust world market and trade system for food and agriculture. Rising food prices are adding inflationary pressures and generating macroeconomic imbalances especially for some low-income countries. In this regard, we will work toward the urgent and successful conclusion of an ambitious, comprehensive and balanced Doha Round. ${ }^{70}$ 
This quote illustrates a new framing of the crisis - one in which insufficient international agricultural trade is a cause of the crisis. The neoclassical economic logic implicit in this framing is that trade liberalization reduces market volatility and spurs economic development. This freetrade-for-food-security framing of the food crisis may appear cynical, since it echoes the standard neoliberal argument for free trade (and the position of agro-powers at the WTO). Yet this new framing is important in several respects. First, the framing of a long-term response to the Global Food Crisis as dependent on completion of the DDA links the crisis and WTO in a new way in global policy discourse. As is discussed further below, this new linkage is very flexible and has been used by both NFEs and NFIs to support their positions at the WTO. In addition, the linking of the food crisis and the WTO alters the perceived geopolitical stakes by creating an expectation among states and other actors that the WTO should produce an outcome that addresses world food insecurity. This framing of the food crisis/WTO relationship is now the "new normal" in global policy discourse. All inter-governmental policy statements on world food security explicitly refer to completing the WTO DDA as an integral part of the solution. ${ }^{71}$ For example, the G20 recently declared that "a more stable, predictable, distortion-free, open and transparent trading system, including as regards agriculture, has a critical role to play to promote food security". ${ }^{72}$

Geopolitical agents were quick to reinforce the idea of free-trade-for-food security in global policy discourse. Then-WTO Director General Pascal Lamy emerged as a principal pitchman by repeatedly pressing this case to the media, government ministers and wider policy and academic audiences. ${ }^{73}$ Below is a characteristic intervention by Lamy to the WTO members:

The reasons why we must conclude the [WTO Doha] Round this year are visible to all of us and they are becoming more critical by the day.... [we] have also witnessed an unprecedented escalation in food prices world wide which has had negative effects particularly on developing countries that depend on imports for their food security or are net food buyers....[a] WTO deal could help soften the impact of high prices by tackling the systemic distortions in the international market for food. ${ }^{74}$

Lamy's quote is typical of statements during the height of the Global Food Crisis that both linked the food crisis to the Doha Round and emphasized the urgency of the situation to prompt 'decisive' action among WTO members. The WTO is not the sole geopolitical agent advancing such a position. Then-World Bank President, Robert Zoellick, argued passionately in the international press that concluding the Doha Round offered a once-in-a-lifetime opportunity to promote food security in developing countries as part of a 'New Food Deal' ${ }^{75}$ At the WTO's 2011 Aid for Trade meeting, UN Secretary General Ban Ki-Moon stressed that the conclusion of the Doha Round would "contribute immensely" to increasing global food security among the poorest and most vulnerable people. ${ }^{76}$ Concluding the Doha Round is affirmed by the UN HighLevel Task Force on the World Food Security Crisis (HLTF), the body which steers the multilateral response to the food crisis and of which the WTO is a member. ${ }^{77}$

This linking of the food crisis and the WTO has caused WTO officials to emerge as new players in global food security policy. Since the crisis the WTO Director General has come to participate on an equal footing with the heads of the FAO and World Food Programme (WFP) in high-level deliberations on world food security. ${ }^{78}$ WTO officials now work alongside experts from the FAO, WFP, and World Bank in inter-agency panels advising the G8 and G20 on policies to address food price volatility and improve agricultural market information. ${ }^{79}$ It is important to 
note that prior to the food crisis the WTO did not actively engage in global policy discussions and/or technical work on food security. In the past, food security issues used to be regarded as beyond WTO officials' competencies and officials regularly deferred to outside experts from the FAO, WFP and academia. The now routinized role of the WTO as a legitimate and authoritative voice on food security affords its officials greater influence over the agenda and norms in the governance of food security than before the crisis. ${ }^{80}$

\section{Negotiating Food Security in the DDA After the Global Food Crisis}

The post-crisis geopolitics of food security illustrate the myriad of ways in which states are deploying the discourse of free-trade-for-food security to seek control over the WTO. There are two discernable phases of this. The first phase ranges from July 2008 to early 2011. During this phase, key events were the July 2008 Ministerial and the December 2009 WTO Ministerial meetings. During this period the top priority for WTO members was to prevent a total collapse of the DDA. It is also during this period when agro-powers began to instrumentalize the Global Food Crisis for such ends. Alieen Kwa of the South Centre, a prominent global South think-tank, reported that behind closed doors at the WTO, food exporting nations were using the crisis to pressure food insecure nations into accepting a WTO deal. ${ }^{81}$ Moreover, the key NFEs (US, EU, Australia and Brazil) instrumentalized the crisis in an effort to roll back food security "friendly" gains tabled in the draft agricultural modalities agreement. During informal discussions among WTO members in 2008 and 2009, NFEs stressed to G33 members and NFIs that in the postcrisis context that the SSM and Special Products were inappropriate policy tools because dumping occurs when prices fall and not increase. ${ }^{82}$ NFEs pointed out that many food insecure countries temporarily reduced tariffs on food imports, an action agro-powers argued was proof that the appropriate policy direction was to deepen liberalization by negotiating lower overall tariff rates.

Agro-powers use of the food crisis to critique the SSM is not simply a technical policy debate but must be understood as part of wider geopolitical struggles. Agricultural tariffs are one of the few policy levers to regulate agricultural markets and smooth out food price fluctuations available in the AoA to the majority of developing WTO members; these states do not have recourse to alternative policies such as price controls or food reserves. ${ }^{83}$ By comparison, agropowers have recourse to more options both under the AoA and also simply because of their structural position in the global agro-food system as NFEs. NFEs' strategy to frame agricultural tariffs as "anti-food security", a framing built on knowledge production by the World Bank and mainstream agricultural economists, seeks to hide a complex reality and asymmetric power relations. Most NFIs and developing country WTO members have relatively low average agricultural tariffs that are a direct result of structural adjustment programs. ${ }^{84}$ Agricultural tariffs remain an important source of public revenue, especially for states lacking effective tax systems. Tariffs on food imports are not unproblematic and do not necessarily lead to improved food security outcomes. However, the post-crisis context, where the free-trade-for-food security discourse is the new normal in global policy debates, has shifted the battleground over agricultural tariffs. The mainstream interpretation of the food crisis has strengthened the position of agro-powers at the WTO and their objective to reduce agricultural tariffs. The post-crisis political economy conditions are supposedly undermining the earlier logic behind the SSM thereby putting food insecure states more strongly on the defensive in agricultural trade negotiations. $^{85}$

Despite agro-powers' critique of the SSM there appears to have been minimal substantive 
inter-state discussion on trade-related food security issues informed by the crisis at the WTO during this first phase. Even though food security is part of the WTO's mandate and is a key issue in the DDA negotiations, a search of declassified official WTO documents published between 2008-2010 confirms that the Global Food Crisis did not feature in the institutions regular inter-state work. ${ }^{86}$ Only one record exists of a discussion among states: a 2009 presentation by a group of LDCs on the crisis at the meeting of a minor WTO sub-committee. ${ }^{87}$ It appears the crisis was discussed informally but not in the key WTO decision-making bodies such as the General Council or Committee on Agriculture, which could have been expected given the prominence of the issue and the WTO's secretariat work on the multilateral response to the food crisis. This lack of WTO-based deliberations on food security is even more curious given that during this period agro-powers made strong statements about importance of the WTO for the solving the food crisis. It appears that during this first period the discourse of free-tradefor-food security was prominent but in comparison there was not a concerted effort to translate this discourse into new trade rules. However, efforts to frame of the WTO as a fix to the crisis spurred considerable counter-geopolitics. In advance of the July 2008 Ministerial, over 200 NGOs mobilizing under the umbrella of "Our World is Not for Sale" launched a campaign directed at the heads of the WTO and global policymakers to reject the WTO as a solution to food crisis. ${ }^{88}$ Global civil society criticized the draft agricultural modalities for not providing much in the way of pro-food security outcomes. In particular, these actors voiced concern that existing WTO rules constrained food-insecure states' (including NFIs) policy space to build up their food security independence, a view that was echoed in a report by the UN Special Rapporteur on the right to food. ${ }^{89}$

A second phase from 2011 to the present is characterized by states' efforts to translate the discourse of free-trade-for-food security into new agricultural trade rules at the WTO. A key turning point was the lead up to the 2011 WTO Ministerial meeting in Geneva when members identified food security as a high priority issue and called for a new program of work on food security to be part of the DDA. ${ }^{90}$ Yet no specific plan was tabled at the 2011 Ministerial as WTO members continued to read food security through different geopolitical lenses, yet all invoking variations of the free-trade-for-food security discourse. For example, Brazil, Russia, India and China (BRICs) identified the “distorting subsidies granted by developed economies” as generating food insecurity. ${ }^{91}$ The Cairns Group of developed and developing net-exporters (which includes Brazil) stressed that "policies that distort production and trade in agricultural products can impede the achievement of long term food security" in a lightly veiled criticism of both US and EU subsidies but also the SSM. ${ }^{92}$ The G33 emphasized the importance of Special Products and the SSM to enable them to achieve food security and development goals. ${ }^{93}$ The friction over food security at the 2011 Ministerial was notable because even three years after the Global Food Crisis WTO members were still in disagreement on how to treat food security. By comparison in other global policy spaces such as the UN system and G8/G20 states were able to reach consensus far more quickly. Inter-state conflicts over food security at the WTO confirm the importance of this geopolitical agent - the stakes being rules that govern the global ago-food system and distribute its benefits and costs - and the difficulty in forging "consensus" when asymmetric power relations are brought to the fore.

The most recent illustration of geopolitical struggles for control of the WTO occurred at the December 2013 WTO Ministerial in Bali, Indonesia. An important development in the lead up to the Bali Ministerial was the efforts to achieve a so-called early harvest on trade issues, including agriculture and food security. The early harvest was put forward as a means to reach a 
compromise at Bali that would address the immediate food security concerns of NFIs and other food insecure countries (which have become more acute since 2008) and also signal that the WTO has an important role in world food security. A key element of the early harvest was based on an earlier G33 proposal to omit public food stockholding to be counted as trade-distorting support and thereby not be subject to the subsidy limits under the AoA. ${ }^{94}$ A second element in the proposed early harvest was a G33 call for states to be exempt from WTO legal challenge in cases where implementing stockholding programs for food security surpasses the subsidy spending limits in the AoA. ${ }^{95}$ The G33 proposal on its own is not radical as it is consistent with the post-crisis global policy consensus that includes an emphasis on greater public action and investment in food security. ${ }^{96}$ Yet this proposal is controversial at the WTO because NFEs/ agropowers view it with scepticism and fear it would set a precedent of permitting trade policies that deviate from the AoA's norms and rules. Perhaps not fully appreciated is the degree to which the G33 proposal challenges the underlying logic of existing WTO rules by reopening debate on how to define and classify an agricultural subsidy, which agro-powers recognize risks unsettling not just the DDA but the original intention of the Uruguay Round agreement to remake agricultural food trade along the logic of comparative advantage and economies of scale. Division over the G33 proposal is strongest between NFEs and NFIs and does not fall along North-South lines, with the US, Brazil, EU, Canada, Australia, Thailand and Argentina particularly hostile to rewriting WTO rules to accommodate public food stockholding. ${ }^{97}$ Food stockholding emerged as the most contentious issue at the WTO Ministerial in Bali and threatened to derail the talks. Disagreement between the US and India (which recently passed a national food stockholding bill) in Bali on food stockholding garnered the most international attention, and required brokering by the WTO Director General to reach a conclusion. However, the geopolitics of food stockholding should not be viewed solely as a US versus India but instead these pivotal agropowers were representing larger constituencies at the WTO, in this case NFEs and NFIs/food insecure states respectively. The Bali Ministerial has been spun by the WTO as a major success and its outcome, the Bali Package, contained an interim agreement with conditions for when food stockholding programs may be exempt from the AoA and legal challenge. ${ }^{98}$ However, the Bali Package on food stockholding is only an interim agreement. States are intended to negotiate permanent and comprehensive rules on food stockholding for consideration at the 2015 WTO Ministerial. The prominence and divisiveness of food stockholding at Bali confirms the deepening of geopolitical struggles over food security and for control of the WTO.

\section{Geopolitics of food export restrictions}

Geopolitical struggles for control of the global agro-food system are also evident in efforts to create new rules on food export restrictions at the WTO. Food export restrictions are government imposed bans on the export, sale and shipment of staple grains or other strategic foodstuffs. Thirty-three states implemented export restrictions during the crisis. ${ }^{99}$ Food export restrictions were the object of vociferous criticism by established agro-powers, international organizations and academics for aggravating and reinforcing the crisis. ${ }^{100}$ Russia, Ukraine, Argentina, Thailand, Vietnam, and India were singled out for particular criticism, with econometric studies directly linking their export restrictions to the doubling of wheat and tripling rice prices in 2007/2008. ${ }^{101}$ These price spikes spurred a new global policy debate on food export restrictions. Prior to the crisis established NFEs, NFI and most economists had long argued export restrictions were hazardous for the globalized food economy. ${ }^{102}$ Criticism of export restrictions since the food crisis has intensified and is articulated as an international cooperation problem. In 
the wake of the crisis, the WTO called food export restrictions "beggar thy neighbour" policies. ${ }^{103}$ As put by the former head of the International Food Policy and Research Institute (IFPRI):

How effective are these [food export restrictions] responses likely to be? Price controls and changes in import and export policies may begin to address the problems of poor consumers who find that they can no longer afford an adequate diet for a healthy life. But some of these policies are likely to backfire by making the international market smaller and more volatile. ${ }^{104}$

The mainstream economic consensus is that food export restrictions have negative externalities for the global food economy and require more stringent international regulation. ${ }^{105}$ Since the crisis, there has been an emerging global norm in favour of strengthening international rules to regulate food export restrictions. ${ }^{106}$ Philip McMichael argues that this new framing of export restrictions as a global public bad is a highly politicized acts that seeks to legitimate the rhetoric of trade liberalization to advance "neo-liberal food security". ${ }^{107}$

The intensified criticism of food export restrictions masks geopolitical struggles because such criticism serves an agenda-setting function that has worked to focus blame on certain NFEs' policies while shifting attention away from US and EU agrofuel policies, which are widely recognized as a principal cause of the food crisis. ${ }^{108}$ Lost in this geopolitical blame game is that states implemented export restrictions only after food prices already began to rise; making this an amplificatory but not primary driver of the crisis. In addition, the targeted criticism of emerging NFEs that imposed restrictions obscures the fact that thirty-three countries introduced restrictions, a larger set of states not confined to any region of the world and that included many NFIs. ${ }^{109}$ The widespread use of restrictions by one sixth of the world's states suggests that geopolitical tensions are not likely to be easily papered over. States continue to evoke their sovereign right to protect national food security, a position succinctly expressed by India's foreign minister that "every country must first ensure its own food security" before considering the consequences for international markets. ${ }^{110}$

The WTO was identified early on by states as the appropriate arena to address food export restrictions. ${ }^{111}$ In 2008, the G8 declared it "imperative to remove export restrictions” and resume the Doha Round to introduce "stricter disciplines on these trade actions which prolong and aggravate the situation, and hinder humanitarian purchases of food commodities". ${ }^{112}$ The WTO was a logical choice to address food export restrictions because the AoA includes rules on food export restrictions under Article XXII, which permits them on a temporary basis to address shortages of critical foodstuffs. ${ }^{113}$ Earlier in the Doha Round, WTO members discussed strengthening food export restrictions, however, the view at that time was that these policies were a minor trade issue. ${ }^{114}$ Following the food crisis, export restrictions have featured more prominently in inter-state negotiations of WTO rules. Recent geopolitical contests illustrate a complex dynamic, with one contest occurring between emerging and established agro-powers and another between NFEs and NFIs. At the 2011 WTO Ministerial, the EU tabled a proposal to exempt humanitarian food aid purchases by the WFP from export restrictions. In this case, the EU proposal was a repackaging of an earlier G20 recommendation. ${ }^{115}$ An unexpected twist occurred at the 2011 Ministerial in that certain G20 members, in this case Argentina, Brazil, India and China, rejected the proposal. Rejection of the EU/G20 proposal was not along North- 
South lines, with other G20 members - Indonesia, Chile and Mexico - and most NFIs in favour. According to press reports, emerging agro-powers claimed their rejection of the proposal was on the basis of preventing a precedent that G20 decisions might be interpreted as binding on WTO members. ${ }^{116}$ A critical geopolitics provides an alternative reading that suggests emerging agropowers rejected the EU proposal in order to block an effort by established agro-powers to reset the parameters of the agricultural negotiations since the food crisis. ${ }^{117}$ Emerging agro-powers, in particular Argentina, have sought to foreclose multiple attempts by the EU and US to reopen the DDA negotiating agenda precisely on food export restrictions and related export policy measures. Argentina's position is that doing so is a thinly veiled attack to reduce its agricultural policy space; it relies on restrictions to enhance export competitiveness by indirectly promoting value-added export processing. It also requires export taxes to finance social protection programs. ${ }^{118}$ Therefore the rejection of the EU proposal should not be simply interpreted as case of emerging agro-powers failing to lead on food security as some commentators have suggested. Instead, the rejection of EU proposal on food export restrictions is embedded in deeper geopolitical struggles among agro-powers for control of the WTO.

NFIs have also sought to remake WTO rules on food export restrictions. In April 2008 (some months before the apex of the crisis), Switzerland and Japan introduced a negotiating proposal calling for more stringent criteria to be met before WTO members could impose a restriction, including the establishment of a supranational committee of trade experts to adjudicate the merit of proposed restrictions on a case-by-case basis. ${ }^{119}$ The Swiss-Japanese proposal, which was framed as in the interest of all NFIs, was rejected most fiercely by African states that includes the majority of NFIs. ${ }^{120}$ It turned out that many NFIs rejected the SwissJapanese proposal because it failed to acknowledge the heterogeneity of users of export restrictions. These NFIs feared the proposal would limit their future policy space to respond to similar food crises. In the July 2008 meeting, WTO members compromised on food export restrictions and agreed to strengthen consultation, information sharing and transparency among WTO members. A second effort by NFIs, this time a proposal developed by Egypt in the lead up to the 2011 WTO Ministerial called for the immediate ban on food export restrictions that would negatively affect NFIs and LDCs. ${ }^{121}$ The Egyptian proposal was supported by a large coalition of NFIs and food insecure developing countries, including moral support from Japan and Switzerland (which would not have been covered by the proposal). Even non-NFIs such as the Philippines supported the proposal and argued that it should apply more broadly to include other middle-income developing countries whose food insecurity was adversely affected by food export restrictions during the crisis. ${ }^{122}$ In the lead up to the Ministerial, the US, Australia and Brazil blocked the Egyptian proposal claiming that changes to WTO rules on export restrictions must be part of the wider agricultural negotiation, not implemented through extraordinary means such as an immediate ban on restrictions. Whereas NFIs hoped the Egyptian proposal would be included in an "early harvest” at the 2013 Bali Ministerial, export restrictions were not included in the final agenda.

Conventional analyses of the debate of food export restrictions at the WTO largely limit themselves to evaluating whether existing proposals and other solutions would enhance transparency and reduce world market volatility. ${ }^{123}$ Yet a critical geopolitics provides an alternative reading. Any specific proposal on food export restrictions at the WTO, regardless of the merits of its intentions, cannot be understood outside of the wider geopolitical stakes of the DDA. Even a small shift on one issue such as export restriction has broader ramifications for rescaling power relations in the global agro-food system (hence Argentina's rejection of the EU 
proposal). The inability of NFIs to advance their interests at the WTO can be read in two ways. First, agro-powers have a collective interest in preventing the further carving out of exceptions for NFIs and expanding differentiation of how WTO rules apply to different categories of states beyond what already exists under special and differential treatment. Established and emerging agro-powers appear equally vigilant against rebalancing WTO rules in favour of NFIs, which they regard as export markets. A second reading is that contests among established and emerging agro-powers at the WTO are creating political conditions generally less favourable for NFIs. Despite disagreement among agro-powers on the G20/EU proposal, emerging and established agro-powers in equal parts rejected the Egyptian proposal and managed to keep food export restrictions off the agenda at Bali. Recall that during the Uruguay Round, NFIs were successful in securing a side agreement to address rising food prices. In the DDA, where agro-power is far more widely distributed between Northern and Southern NFEs, NFIs appear to be fairing less well as a group. However, these new power relations at the WTO are also a new source of geopolitical struggles. Behind closed doors at the WTO NFIs have criticized emerging agropowers for not supporting their interests. Conflict among NFIs and emerging agro-powers over export restrictions may be an important rift that could erode the strength of South-South bargaining coalitions thus at the WTO (i.e., the Ag-G20). ${ }^{124}$ In the same instance, the success of emerging agro-powers to resist NFIs and established agro-powers' demands for new rules on food export restrictions confirms that geopolitical contests over food security are far more polycentric than in the previous GATT/WTO trade rounds.

\section{CONCLUSION}

The WTO is a key site of geopolitical struggle over the global agro-food system. Inter-state conflicts over control of the international trade system are decades old; however, the WTO AoA was a decisive historical event that institutionalized the geopolitics of the global agro-food system. The Global Food Crisis occurred during a moment of deep institutional paralysis at the WTO that resulted in a strategic appropriation of the crisis by states and geopolitical agents to revive the Doha Round. An unexpected development is the external legitimization of the WTO as credible actor on food security through its inclusion into global networks of food security policymaking and governance (e.g., HLTF, inter-agency panels). A less surprising but poorly understood development is that the Global Food Crisis has resulted in a deeper institutionalization of inter-state contests for control of the WTO. Emerging and established NFEs and NFIs efforts to reshape WTO rules - the discourse of free-trade-for-food security, agricultural dumping, regulating food export restrictions, etc. - confirm heightened rather than diminished struggles for control of this geopolitical agent. Agro-powers recognize that the Global Food Crisis has shaken the confidence of net-food importers in the multilateral trade system. ${ }^{125}$ At the same time, the Global Food Crisis has raised the geopolitical stakes of the WTO by placing food security higher on the DDA negotiating agenda. Recent efforts for an early harvest on food security, such as food stockholding, is marked by more fractured geopolitical tensions that illustrate reinvigorated inter-state contests for control of the WTO.

This article contributes to advancing a critical geopolitics approach to the study of power in the global agro-food system. The emergence of new agro-powers from the Global South as major players in rulemaking at the WTO confirms, and reinforces the shift towards, a new spatial reconfiguration of production and power in the global agro-food system towards polycentrism. At the WTO, there has been a noticeable shift in the geopolitics of food security since the Global 
Food Crisis. Debates over increasing opposition by established and emerging agro-powers to the SSM and disciplines on food export restrictions illustrates that global food politics are not adequately captured by a North-South framing. The analytical use of the categories of NFEs and NFIs brings into sharp relief more complex power relations and struggles in the prevailing geopolitical food order than is commonly assumed in the literature. The failure of NFIs to obtain special food import financing earlier in the DDA and more recently exemptions from food export restrictions shows that even though agro-power is presently shared by a larger number of Northern and Southern states, such a rescaling of power in the global food system may be resulting in conditions less advantageous to the most food insecure states. A transition towards a polycentric global agro-food system requires adjusting our analytical gaze to new configurations of power, asymmetries and vulnerability; this means taking seriously South-South conflicts but also situating pre-existing North-South struggles in a new global context, which may be altering both their dynamics and their geopolitical significance.

\section{NOTES}

${ }^{1}$ For example, in 2008, Archer Midland Daniels (ADM) third-quarter profits increased by 42\%, Cargill Inc.'s profits jumped 86\%, and Bunge Ltd.'s earnings rose by nearly 200\%. Reported in Wall Street Journal, 'Grain Companies' Profits Soar As Global Food Crisis Mounts, April 30 2008. Available at:

Hhttp://online.wsj.com/article/SB120949327146453423.html

${ }^{2}$ Author calculation based on data from Food and Agriculture Organizations (FAO) State of Food Insecurity in the World (Rome: FAO 2012).

${ }^{3}$ J.W. Moore, 'Transcending the Metabolic Rift: A Theory of Crises in the Capitalist World-Ecology', Journal of Peasant Studies 38/1 (2011); M. Schneider and P. McMichael, 'Deepening, and Repairing, the Metabolic Rift', Journal of Peasant Studies 37/3 (2010). P Conceição and R.U. Mendoza, ‘Anatomy of the Global Food Crisis’ Third World Quarterly 30/6 (2009).

${ }^{4}$ S. Horton, 2009. “The 1974 and 2008 food price crises: déjà vu?” in J. Clapp and M. Cohen (eds.) The Global Food Crisis: Governance challenges and opportunities (Waterloo: Wilfrid Laurier Press), pp. 29-42;.Lang, T. I. M. 2010. Crisis? What Crisis? The Normality of the Current Food Crisis. Journal of Agrarian Change 10 (1):87-97

${ }^{5}$ On the geopolitical social see Cowen and Smith (2009), note 16. On hunger as a form of structural violence see G. Kent, 'Children as Victims of Structural Violence,' Societies Without Borders 1/1 (2006).

${ }^{6}$ See H. Friedmann, 'The Political Economy of Food: The Rise and Fall of the Postwar International Food Order', The American Journal of Sociology 88 (1982); P. McMichael (ed), The Global Restructuring of Agro-Food Systems (Ithaca: Cornell University Press 1994).

${ }^{7}$ On 'geoeconomics' see D. Cowen and N. Smith, ‘After Geopolitics? From the Geopolitical Social to Geoeconomics,' Antipode 41/1 (2009).

${ }^{8}$ Friedmann, Harriet, and Philip McMichael. 1989. Agriculture and the State System: The Rise and Decline of National Agricultures, 1870 to the present. Sociologia Ruralis 29 (2):93-117.

${ }^{9}$ McMichael, Philip, ed. 1994. The Global Restructuring of Agro-Food Systems. Ithaca: Cornell University Press; Bonanno, Alessandro, Lawrence Busch, William H. Friedland, Lourdes Gouveia, and Enzo Magnione, eds. 1994. From Columbus to ConAgra: The Globalization of Agriculture and Food. Lawrence, Kansas: University of Kansas; Press.Otero, Gerardo, Gabriela Pechlaner, and Efe Can Gürcan. 2013. The Political Economy of "Food Security" and Trade: Uneven and Combined Dependency. Rural Sociology 78 (3):263-289.

${ }^{10}$ J.G. Ruggie, 'International Regimes, Transactions, and Change: Embedded Liberalism in the Postwar Economic 
Order', International Organization 36/2 (1982).

${ }^{11}$ FAO, 2009. Country responses to the food security crisis: Nature and preliminary implications of the policies pursued (Rome: FAO), pp. 24-29.

${ }^{12}$ See McMichael (1994) note 8; M. Margulis, N. McKeon and S.M., Borras, Jr., 'Land Grabbing and Global Governance: A Critical Introduction', Globalizations, 13/1 (2013).

${ }^{13}$ I differentiate here between studies of specific international trade policies or the global aspects of the food crisis to those of the multilateral trading system. Many studies address the first two but there has been no critical geopolitical analysis of the third. The key works on this topic are by trade policy and international law scholars. See S. Heri and C. Häberli, Report on World Food Crisis: Are Trade Rules a Problem or a Way Forward? (Berne, Switzerland: World Trade Institute 2008) and T.J. Schoenbaum, 'Fashioning a New Regime for Agricultural Trade: New Issues and the Global Food Crisis.’ Journal of International Economic Law 14/3 (2011). For critical geopolitical work on the global aspects of the crisis see Jarosz, Lucy. 2009. Energy, Climate Change, Meat, and Markets: Mapping the Coordinates of the Current World Food Crisis. Geography Compass 3 (6):2065-2083; Weis, Tony. 2010. The Accelerating Biophysical Contradictions of Industrial Capitalist Agriculture. Journal of Agrarian Change 10 (3):315-341.

${ }^{14}$ On counter-geopolitics, see Burnett and Sommervillle, Essex and Le Billion in this issue.

15 The key study is R. Wolfe, 1998. Farm Wars: The Political Economy of Agriculture and the International Trade Regime. Basingstoke, UK: Macmillan. Other studies that confirm agri-business did not play a direct role in negotiating WTO agriculture rules include R. Paarlberg, 1997. Agricultural Policy Reform and the Uruguay Round: Synergistic Linkage in a Two-Level Game? International Organization 51 (03):413-444; R. Marlin-Bennett, 1993. Food Fights: International Regimes and the Politics of Agricultural Trade Disputes. Langhorne, Pennsylvania: Gordon and Breach; C.L. Davis, 2003. Food fights over free trade: how international institutions promote agricultural trade liberalization: Princeton University Press; Kay, A., \& Ackrill, R. (2009). Institutional Change in the International Governance of Agriculture: A Revised Account. Governance, 22(3), 483-506.

${ }^{16}$ S. Sell, Private Power, Public Law: The Globalization of Intellectual Property Rights (Cambridge: Cambridge University Press 2003); Woll, C. (2008). Firm interests: How governments shape business lobbying on global trade: Cornell University Press.

${ }^{17}$ Rosset, Peter. 2008. Food sovereignty and the contemporary food crisis. Development 51 (4):460-463; McKeon, N. 2009. The United Nations and Civil Society: Legitimating Global Governance - Whose Voice? New York: Zed Books.

${ }^{18}$ Aaronson, Susan Ariel, and J. Zimmerman. 2007. Fair Trade? How Oxfam Presented a Systemic Approach to Poverty, Development, Human Rights, and Trade. Human Rights Quarterly 28 (4):998-1030; Hopewell, K. 2009. "The Technocratization of Protest: Transnational Advocacy Organizations and the WTO,” in Fastenfest, D., ed. Engaging Social Justice: Critical Studies of 21st Century Social Transformation. Leiden: Brill; Robertson, David. 2000. Civil Society and the WTO. World Economy 23 (9):1119-1134; O'Brien, Robert, Anne Marie Goetz, Jan Aart Scholte, and Marc Williams. 2000. Contesting Global Governance: Multilateral Economic Institutions and Global Social Movements. Cambridge, UK: Cambridge University Press.

${ }^{19}$ Agnew, John. 1994. The territorial trap: The geographical assumptions of international relations theory. Review of International Political Economy 1 (1):53-80; Mann, Michael. 1997. Has globalization ended the rise and rise of the nation-state? Review of International Political Economy 4 (3):472-496; Glassman, Jim. 1999. State power beyond theterritorial trap': the internationalization of the state. Political Geography 18 (6):669-696.

${ }^{20}$ Higgott, Richard A, and Andrew Fenton Cooper. 1990. Middle power leadership and coalition building: Australia, the Cairns Group, and the Uruguay Round of trade negotiations. International Organization 44 (4):589-632; Kahler, Miles. 1992. Multilateralism with small and large numbers. International Organization 46 (03):681-708. 
${ }^{21}$ The WTO preserves a strong role for the state in agricultural public policy by codifying such practices under international law. Even in the current neoliberal moment, agriculture remains the least liberalized sector in international trade. This is in sharp contrast to the depth of liberalization of industrial goods, services, and intellectual property rights. For example, export restrictions of industrial goods have been illegal under the multilateral trading system for decades yet are permitted for agriculture goods. Third, states are not black boxes that represent a generalized agro-food interest. The structure of WTO negotiations, the so-called Single Undertaking, requires stats to make many sets of strategic trade-offs across all the sectors under negotiation in a round (e.g., agriculture, industrial goods, intellectual property rights, services, public procurement, etc.). Within this negotiating process, states must continually accommodate when developing their negotiation positions at the WTO: domestic interests, which include competing agro-food and non-agro-food constituents); the interests of their negotiating partners with whom they must compromise with and accommodate, and; the state's own national policy goals, which can be fractured as well with different departments and agencies having competing interests. Negotiations at the WTO are highly dynamic and iterative process and outcomes are influenced by a myriad of shifting state strategies and external, often unpredictable events. Under these conditions, in my view, it is too much of an intellectual stretch highly unlikely that WTO outcomes can be claimed to represent the preferred or aggregated interests of global agro-business. This view requires us to view the WTO as operating as a direct input-output type of transmission mechanism; this view does not match the reality of multilateral trade negotiations and economic diplomacy.

22 J. Clapp and D.A. Fuchs (eds.), Corporate Power in Global Agrifood Governance (Cambridge: Massachusetts Institute of Technology Press 2009); K. Morgan, T. Mardsen and J. Murdoch. Worlds of Food: Place, Power, and Provenance in the Food Chain (Oxford: Oxford University Press 2006).

${ }^{23}$ Borras, Saturnino M., Jennifer C. Franco, and Chunyu Wang. 2013. The Challenge of Global Governance of Land Grabbing: Changing International Agricultural Context and Competing Political Views and Strategies. Globalizations 10 (1):161-179; S.M. Borras, J. Franco and C. Wang, 'Competing Political Tendencies in the Global Governance of Land Grabbing, Transnational Institute (2012); A.H. Akram-Lodhi, 'Contextualising Land Grabbing: Contemporary Land Deals, the Global Subsistence Crisis and the World Food System', Canadian Journal of Development Studies 33/2 (2012); S.M. Borras., P. McMichael and I. Scoones, 'The Politics of Biofuels, Land and Agrarian Change: Editors' Introduction.’ Journal of Peasant Studies 37/4 (2010).

24 'Agro-power' is a heuristic employed in this article that refers to actors, in this case specifically (but not exclusively) the State and its control of the production, consumption and distribution of food at the national and transnational level through the direct/indirect physical control over food and food-related resources (i.e., inputs, transportation, technology, knowledge) and instrumental and ideological control of governance institutions (i.e., real and virtual markets, formal international organizations, global norms and principles, etc.). Which actors have, and how they exert, agro-power is historically specific to particular geopolitical orders. As such, agro-power is always relational and can be enjoyed by one or multiple actors. For an analysis for private forms of agro-power see Clapp and Fuchs (2009), note 23.

${ }^{25}$ J. Clapp and S. Murphy, ‘The G20 and Food Security: a Mismatch in Global Governance?’, Global Policy 4/2( 2013).

${ }^{26}$ K. Hopewell, 'New Protagonists in Global Economic Governance: The Rise of Brazilian Business at the WTO.' New Political Economy (in press.

${ }^{27}$ K. Hopewell, "From Dependent Development to Globalized Development: The Evolution of State-Business Relations in Brazil." Presented at the "Emerging Market Multinational Corporations and the State: Implications for Transnational Activity” Workshop, Parma, Italy, June 2012.

${ }^{28}$ E. Woertz, ‘The Governance of Gulf Agro-Investments,' Globalizations 10/1 (2013).

${ }^{29}$ See Hopewell, note 27.

${ }^{30}$ This is too large literature in International Development studies. 
${ }^{31}$ S. Sassen (2003). The participation of states and citizens in global governance. Indiana Journal of Global Legal Studies, 10(1), 5-28.

${ }^{32}$ S.M. Borras, J. C. Franco, S. Gomez, C. Kay, and M. Spoor, 'Land Grabbing in Latin America and the Caribbean', Journal of Peasant Studies 39/3-4.

${ }^{33}$ Cowen and Smith (2009); Margulis et al (2013)

${ }^{34}$ In general net-food exporters are nations characterized by a relatively high degree of food self-sufficiency in key basic food stuffs even though they may still import significant amounts of food and non-food agricultural commodities. These imports include intermediary inputs for transnational food production (i.e., Chinese garlic and Greek Olives for the making of North American frozen pizzas) and/or luxury consumer foods (i.e., high-end European chocolate). On the other hand, net-food importers are often not self-sufficient in key basics foodstuffs and most import these. However many net-food imports may still export some food (e.g., cacao, coffee, etc.) and nonfood agricultural commodities (e.g., cotton). See Ng, F., \& Aksoy, M. A. (2008). Who Are The Net Food Importing Countries? (Washington, D.C.: World Bank); Valdés, A., \& Foster, W. (2012), Net food-importing developing countries: who they are, and policy options for global price volatility. ICTSD Programme on Agricultural Trade and Sustainable Development-Working Paper.

${ }^{35}$ Hawthorne, H. (2013). Least Developed Countries and the WTO: Special Treatment in Trade (London and New York: Palgrave Macmillan).

${ }^{36}$ Whether a country is a net-food importer or net-food exporter is highly fluid and always relational to other states. Other important factors include including colonial and post-colonial histories, structural changes in the global agrofood system, national food policies, natural geography, and time. The fluidity of this category is observable in countries that fluctuate considerably along this continuum such as China and India, which are major food producers and exporters but also highly dependent on imports of animal feed and oilseeds and pulses.

${ }^{37}$ Valdés \& Foster (2012), pg. 9., note 35.

${ }^{38}$ Data on countries' trade profiles are from the United States Department of Agriculture (USDA) website, available at: Hhttp://www.ers.usda.gov/topics/international-markets-trade/countries-regions/india/trade.aspxH.

${ }^{39}$ McMichael, P. 2000. 'A Global Interpretation of the Rise of the East Asian Food Import Complex.' World Development 28/3: 409-424.

40 J. Agnew, 'The Territorial Trap: The Geographical Assumptions of International Relations Theory.' Review of International Political Economy 1/1 (Spring 1994).

${ }^{41}$ See Agnew note 19; also R.W. Cox 'Multilateralism and World Order.' Review of International Studies 18/2 (1992); S. Gill, 'Economic Globalization and the Internationalization of Authority: Limits and Contradictions.' Geoforum 23/3 (1992).

${ }^{42}$ I thank Melanie Sommerville for the suggesting the term geopolitical agents. See also G. Kearns, 'Progressive Geopolitics’, Geography Compass 2/5 (2008) pp. 1607-1609.

${ }^{43}$ The UN Rome-based food agencies are: the Food and Agriculture Organization (FAO); World Food Programme (WFP), and; the International Fund for Agriculture (IFAD).

${ }^{44}$ D. Drache, 'The Short But Amazingly Significant Life of the International Trade Organization (ITO). Free Trade and Full Employment: Friends or Foes Forever?', working paper available at: Hwww.robarts.yorku.ca/projects/wto/index.htmlH.

${ }^{45}$ Friedmann, Harriet. 1982. The Political Economy of Food: The Rise and Fall of the Postwar International Food 
Order. The American Journal of Sociology 88:248-286.

${ }^{46}$ Friedmann, Harriet, and Philip McMichael. 1989. Agriculture and the State System: The Rise and Decline of National Agricultures, 1870 to the present. Sociologia Ruralis 29 (2):93-117.

${ }^{47}$ Based on authors historical study of GATT negotiations.

${ }^{48}$ R. Wolfe, Farm Wars: The Political Economy of Agriculture and the International Trade Regime (London: Macmillan 1998); W.D. Coleman, W. Grant, W. and T. Josling, Agriculture in the New Global Economy (Northhampton, MA: Edward Elgar 2004).

${ }^{49}$ W. Grant, 'Agricultural Trade.' In D. Kelly and W. Grant (Eds), The Politics of International Trade in the TwentyFirst Century: Actors, Issues, and Regional Dynamics (Houndsmill, Basingtoke, Hamshire: Palgrave Macmillan 2005).

${ }^{50}$ See R. Wolfe (1999), note 48; W.D. Coleman, W. Grant, W. and T. Josling, Agriculture in the New Global Economy (Northhampton, MA: Edward Elgar 2004. The other two are the Agreement on the Application of Sanitary and Phytosanitary Measures (SPS), and Agreement on Trade-Related Intellectual Property Rights (TRIPS). The SPS established international standards for food safety and criteria that specifies determines when states may reasonably restrict agricultural trade to protect human, animal and plant health; TRIPS required that WTO members put in place strong national intellectual property rights regimes including for geographical indicators of agricultural goods (e.g., Parma ham, Champagne, etc.) and plant variety protection.

${ }^{51}$ M.E. Margulis, 'The Regime Complexity for Food Security: Implications for the Global Hunger Challenge', Global Governance 19/1 (2013); R. Zhang. Food Security: Food Trade Regime and Food Aid Regime. Journal of International Economic Law 7/3 (2004):565-584.

${ }^{52}$ WTO (1994) Decision on Measures Concerning the Possible Negative Effects of the Reform Programme on LeastDeveloped and Net-Food Importing Developing Countries).

53 J. Clapp, 2006 'WTO Agriculture Negotiations: Implications for the Global South’, Third World Quarterly 27/4; R. Wolfe, 2009. The special safeguard fiasco in the WTO: the perils of inadequate analysis and negotiation. World Trade Review 8 (04):517-544; Pritchard, B. (2009) "The long hangover from the second food regime: A worldhistorical interpretation of the collapse of the WTO Doha Round, Agriculture and Human Values 26, pp. 297-307.

${ }^{54}$ Hopewell 2013 (see note 23); A. Narlikar and D. Tussie, 'The G20 at the Cancun Ministerial: Developing Countries and Their Evolving Coalitions in the WTO.' World Economy, 27/7 (2004); Wade, Robert H. 2011. Emerging World Order? From Multipolarity to Multilateralism in the G20, the World Bank, and the IMF. Politics \& Society 39 (3):347-378.

55 da Conceição-Heldt, Eugénia. 2013. Emerging Powers in WTO Negotiations: The Domestic Sources of Trade Policy Preferences. The International Trade Journal 27 (5):431-449.Scott, James. 2010. South-South trade and North-South politics: Emerging powers and the reconfiguration of global governance. Brooks World Poverty Institute (BWPI) Working Paper No. 131; Narlikar, Amrita. 2010. New powers in the club: the challenges of global trade governance. International Affairs 86 (3):717-728; J. Clapp (2006), note 54.

${ }^{56}$ Clapp, Jennifer. 2004. WTO Agricultural Trade Battles and Food Aid. Third World Quarterly 25 (8):1439-1452.

${ }^{57}$ Wise, T.E., 'The Paradox of Agricultural Subsidies: Measurement Issues, Agricultural Dumping, and Policy Reform.' Global Development and Environment Institute Working paper no. 04-02 (2004); Murphy, S., Lilliston, B., and Lake, M. 'WTO Agreement on Agriculture: A Decade of Dumping.' Minneapolis: Institute for Agricultural Trade Policy (2005).

${ }^{58}$ J. Clapp, 2006, note 53; WTO, 2008. Draft Modalities (Geneva: WTO). 
${ }^{59}$ Collier, P. (2006). Why the WTO is Deadlocked: And What Can Be Done About It. World Economy, 29(10), 14231449; Narlikar, A., \& Wilkinson, R. (2004). Collapse at the WTO: a Cancun Post-Mortem. Third World Quarterly, 25(3), 447-460.

${ }^{60}$ World Trade Organization, 'Proposal to Implement the Marrakesh Ministerial Decision in Favour of LDCS and NFIDCS.' (Geneva: WTO 2001).

${ }^{61}$ Forthcoming publication by author.

${ }^{62}$ W Scott, James, and Rorden Wilkinson. 2010. What Happened to Doha in Geneva? Re-engineering the WTO's Image While Missing Key Opportunities. European Journal of Development Research 22 (2):141-153; Clapp, Jennifer. 2009. Food Price Volatility and Vulnerability in the Global South: considering the global economic context. Third World Quarterly 30 (6):1183-1196.,

${ }^{63}$ Pritchard, B. 'The Long Hangover from the Second Food Regime: A World-Historical Interpretation of the Collapse of the WTO Doha Round.’ Agriculture and Human Values 26/4 (2009): 297-307.

${ }^{64}$ For the purpose of analysis the paper I stylize the debate as consisting of two ideal-type groups. Doing so provides a more straightforward route to examine the role that each group assigns to global political economy dynamics, particularly international trade, as causal factors, and as potential resolution, to the crisis.

${ }^{65}$ This includes the World Bank, IMF, International Food Policy Research Institute (IFPRI), and Organization for Economic Cooperation and Development (OECD). This includes the UN Food and Agriculture Organization (FAO). Even though this geopolitical agent is more accessible to global civil society organizations, its knowledge production activities is similar to the organizations listed above.

${ }^{66}$ Key studies include: N. Alexendratos, 'Food Price Surges: Possible Causes, Past Experience, and Longer Term Relevance.' Population and Development Review 34/4; FAO, 'Soaring Food Prices: Facts, Perspectives, Impacts and Actions Required (Rome: FAO 2008); D. Headey and S. Fan, 'Anatomy of a Crisis: The Causes and Consequences of Surging Food Prices.' Agricultural Economics 39 (Supplement 2008) pp. 375-391; D. Mitchell, 'A Note on Rising Food Prices.' (Washington: World Bank 2008); C.P. Timmer, 'The Causes of High Food Prices.' (Manilla: Asian Development 2008).

${ }^{67}$ Holt-Giménez, E. and Shattuck, A., 2011. 'Food crises, food regimes and food movements: rumblings of reform or tides of transformation?', The Journal of Peasant Studies 38(1):109-144.; P. McMichael, 'A Food Regime Analysis of the 'World Food Crisis", Agricultural and Human Values 26/4 (2009); P. McMichael, 'Peasant Prospects in the Neoliberal Age', New Political Economy 11/3 (2006) pp. 407-418; A.A. Desmarias, La Via Campesina: Globalization and the Power of Peasants (London: Verso Books 2007).; Oxfam International, 'A Billion Hungry People' (London: Oxfam International 2008); ActionAid, '10 Point Manifesto to End Hunger.' (London: ActionAid 2008); Institute for Agriculture Trade Policy, 'Turning High Prices Into An Opportunity: What is Needed?' (Minneapolis: Institute for Agriculture Trade Policy 2008); W. Bello, Food Wars (London: Verso 2009).

${ }^{68}$ Ghosh, Jayati. 2010. The Unnatural Coupling: Food and Global Finance. Journal of Agrarian Change 10 (1):7286.

${ }^{69}$ Scott, James, and Rorden Wilkinson. 2010. What Happened to Doha in Geneva? Re-engineering the WTO's Image While Missing Key Opportunities. European Journal of Development Research 22 (2):141-153; Bouet, Antoine, and David Laborde. 2010. Assessing the potential cost of a failed Doha Round. World Trade Review 9 (2):319.

${ }^{70}$ G8, ‘G8 Leaders Statement on Global Food Security.' (Hakkaido, Japan: G8 2008), p. 2.

${ }^{71}$ For example see: FAO, Declaration of the High Level Conference on World Food Security: The Challenges of Climate Change and Bioenergy, 5 June (Rome: FAO 2008); Group of Eight (G8), 'G8 Efforts Towards Global Food 
Security' (L’Aquila, Italy: G8 2008).

${ }^{72}$ G20 Leaders Declaration Los Cabos, Mexico, June 19, 2012

${ }^{73}$ Pascal Lamy's term as WTO Director General ended August 31 2013. His successor is the Brazilian diplomat Roberto Azevêdo.

${ }^{74}$ WTO, 'Lamy says food crisis adds urgency to concluding the Round (Geneva: WTO 2008).

${ }^{75}$ R. Zoellick, ‘A 10-point plan for tackling the food crisis’ (Washington: World Bank 2008).

${ }^{76}$ Ban Ki-moon. Keynote speech at the Third Global Review of Aid for Trade. 19 July 2011. Available at: http://wto.org/english/tratop_e/devel_e/a4t_e/global_review11_prog_e.htm

${ }^{77}$ United Nations (UN), Updated Comprehensive Framework for Action (Geneva: UN 2010).

${ }^{78}$ The WTO Director General is a member of the Chiefs Executive Board (CEB), which brings together the heads of major international organizations across the UN and Bretton Woods system to coordinate policy. The CEB is chaired by the UN Secretary General.

${ }^{79}$ FAO, IFAD, WTO and WFP UNCTAD. 2011. Price Volatility in Food and Agricultural Markets: Policy Responses. Food and Agricultural Organization; Information on the Agricultural Market Information System (AMIS) available at: http://www.amis-outlook.org/.

${ }^{80}$ M.E. Margulis, 'Global Food Governance: The Committee for World Food Security, G8/G20 and the Comprehensive Framework for Action,' In R. Rayfuse and N. Wiesfelt (eds.), The Challenge of Food Security (Edward Elgar Publishers 2012); WTO, Coherence in Global Economic Policy Making: Report by the DirectorGeneral (Geneva: WTO 2011)

${ }^{81}$ A. Kwa, ‘Food Crisis Linked to Doha Deal.’ (International Press Service 8 May 2008).

${ }^{82}$ Authors confidential interviews with WTO delegates, 2008 and 2009.

${ }^{83}$ This is the neoliberal argument that developing countries currently have too much "water" in their tariffs and should thus further liberalize.

${ }^{84}$ UNCTAD, 2008. Addressing the Global Food Crisis: Key trade, investment and commodity policies in ensuring sustainable food security and alleviating poverty (Geneva: UNCTAD); Bello, Walden. 2008. How to manufacture a global food crisis. Development 51 (4):450-455; Bernstein, Henry. 1990. Agricultural 'modernisation' and the era of structural adjustment: Observations on Sub-Saharan Africa. The Journal of Peasant Studies 18 (1):3-35.

${ }^{85}$ See S. Sharma (2010). G33 takes offensive in WTO battle on SSM, Third World Network. Available at: http://www.twnside.org.sg/title2/wto.info/2010/twninfo100210.htm

${ }^{86}$ Author's search of declassified WTO documents, WTO news releases and media reporting.

${ }^{87}$ This is a summary report presented by African countries describing a workshop organized by a Geneva-based NGO, the Centre for Socio-Economic Development (CSEND), made to the WTO's Sub-Committee on Least Developed Countries. That was in 2009

${ }^{88}$ See Our World is Not For Sale 'The WTO's Doha Round Will Not Solve the Global Food Crisis - Time for Real Solutions.’ (2008). Available at: Hhttp://www.iatp.org/files/451_2_102892.pdf

${ }^{89}$ Institute for Agricultural Trade Policy, 'Seven Reasons Why the Doha Round Will Not Solve the Food Crisis (Minneapolis: IATP 2008); O. De Schutter, Compatibility of the WTO and the Post-Global Food Crisis Agenda: 
Putting Food Security First in the International Trade System. (December 2011).

${ }^{90}$ At the last WTO ministerial meeting in December 2011, WTO members supported launching a 'work programme' on trade-related responses to mitigate the impact of food market prices and volatility, the outcome of which will be presented to trade ministers at the next WTO ministerial meeting in 2013 for political endorsement.

${ }^{91}$ BRICS Trade Ministers, ‘Ministerial Declaration: 14 December’ (Geneva: WTO 2011).

${ }^{92}$ Cairns Group, ‘Ministerial Declaration: 15 December’ (Geneva: WTO 2011).

${ }^{93}$ G33, ‘Ministerial Communiqué: 14 December’ (Geneva: WTO 2011).

${ }^{94}$ C. Bellmann, J. Hepburn, E. Krivonos and J. Morrison (2013) ‘G-33 Proposal: Early Agreement on Elements of the Draft Doha Accord to Address Food Security,' (International Centre for Trade and Sustainable Development: Geneva, Switzerland); Bridges Weekly Trade News Digest, 'Developing Countries Table Food Security Proposal at WTO,' 14 November 2012.

${ }^{95}$ F. Galtier, 'The need to correct WTO rules on public stocks' available at: Hhttp://agents.cirad.fr/pjjimg/franck.galtier@cirad.fr/Note_ENG_pdf

${ }^{96}$ Brazil's Zero Fome (Zero Hunger) program is such a food stockholding scheme as is the World Food Programme recent Purchase for Progress program.

${ }^{97}$ Kanaja Raja, “Agri chair reports on consultations on G33, G20 proposals,” Third World Economics, Issue No. 550, 1-15 Aug 2013, pp9-11; Bridges Trade Digest News Weekly, "WTO members cautiously welcome new farm proposals,” 20 December 2012.

${ }^{98}$ WTO, 2013. Public Stockholding for Food Security Purposes: Draft Ministerial Declaration. 6 December.

99 Sharma, Ramesh, and Panos Konandreas. 2008. WTO Provisions in the Context of Responding to Soaring Food Prices. In FAO Commodity and Trade Policy Research Working Paper No. 25. Rome: FAO; Howse, Robert, and Tim Josling. 2012. Agricultural Export Restrictions and International Trade Law: A Way Forward. International Food \& Agricultural Trade Policy Council, Position Paper September.

${ }^{100}$ Ramesh Sharma of the FAO reported that over a hundred opinion-editorials critical of export restrictions have been published in leading international and national newspapers.

101 S. Mitra and T. Josling, 'Agricultural Export Restrictions: Welfare Implications and Trade Disciplines.' (Washington: International Food and Agriculture Policy Council 2008); M. Brahmbhatt and L. Christiaensen, "The Run on Rice.' World Policy Journal 25/2 (June 2008) pp. 29-37.

102 R. Howse and T. Josling, Agricultural Export Restrictions and International Trade Law: A Way Forward (Washington: IPC 2012) p.11.

${ }^{103}$ P. Lamy, 2011. “Lamy cautions against weakening the WTO” 22 March. Available at: http://www.wto.org/english/news_e/sppl_e/sppl189_e.htm

${ }^{104}$ J. Von Braun, Rising Food Prices: What Should Be Done? (Washington: IFPRI 2008), p. 1-2.

${ }^{105}$ See FAO, IFAD, and WFP UNCTAD. 2011. Price Volatility in Food and Agricultural Markets: Policy Responses. Food and Agricultural Organization; Rutten, Martine, Lindsay Shutes, and Gerdien Meijerink. 2013. Sit down at the ball game: How trade barriers make the world less food secure. Food Policy 38 (0):1-10; Goetz, Linde, Thomas Glauben, and Bernhard Brümmer. 2013. Wheat export restrictions and domestic market effects in Russia and Ukraine during the food crisis. Food Policy 38 (0):214-226; Martin, Will, and Kym Anderson. 2012. Export Restrictions and Price Insulation During Commodity Price Booms. American Journal of Agricultural Economics 94 
(2):422-427; Bouët, Antoine, and David Laborde Debucquet. 2012. Food crisis and export taxation: the cost of noncooperative trade policies. Review of World Economics 148 (1):209-233; Gruni, Giovanni. 2013. Going from One Extreme to the Other: Food Security and Export Restrictions in the EU-CARIFORUM Economic Partnership Agreement. European Law Journal 19 (6):864-883; Karapinar, Baris. 2012. Defining the Legal Boundaries of Export Restrictions: A Case Law Analysis. Journal of International Economic Law 15 (2):443-479; Abbott, Philip C. 2012. Export Restrictions as Stabilization Responses to Food Crisis. American Journal of Agricultural Economics 94 (2):428-434; Headey, Derek. 2011. Rethinking the global food crisis: The role of trade shocks. Food Policy 36 (2):136-146; OECD (2010),The Economic Impact of Export Restrictions on Raw Materials, OECD Trade Policy Studies, OECD Publishing.

${ }^{106}$ Howse and Josling (2012) note 100.

${ }^{107}$ McMichael, Philip. 2009. A Food Regime Analysis of the World Food Crisis. Agriculture and Human Values 26 (4):281-295.

108 This contrasts with agrofuels, where early promises by the G8 for international rules remain unfulfilled, and financial speculation on commodities, where action on at the most recent G20 summit has focused on informationsharing and transparency but not in new regulated as had been suggested earlier In 2008 the G8 had pledged to establish guidelines for responsible agro fuels policies that was also endorsed by the UN High Level Task Force on the Global Food Security Crisis. The G8 has since quietly dropped this issue from its work. The G8 and G20 continue to squabble over whether financial speculation in agricultural commodities.

${ }^{109}$ R. Sharma, Food Export Restrictions: Review of the 2007-2010 Experience and Considerations for Disciplining Restrictive Measures (Rome: FAO 2011).

${ }^{110}$ Quoted in K. Bradsher and A. Martin, 'Hoarding Nations Drive Food Costs Ever Higher.' The New York Times, 30 June 2008.

${ }^{111}$ A 2008 proposal by IFPRI to negotiate food export restrictions rules outside the WTO was rejected by states.

${ }^{112}$ G8 (2008) note 71.

${ }^{113}$ WTO, Agreement on Agriculture (Geneva: WTO 1995).

${ }^{114}$ See B. Chatterjee and C. Mukambu, 2011. “Food Export Restrictions: Balance Importers’ and Exporters’ Rights” CUTS CITEE Working Paper, p.5.

115 The G20 in the Cannes Summit Final Declaration stated “...we agree to remove food export restrictions or extraordinary taxes for food purchased for non-commercial humanitarian purposes by the World Food Program and agree not to impose them in the future. In this regard, we encourage the adoption of a declaration by the WTO for the Ministerial Conference in December 2011.”

${ }^{116}$ ICTSD, 2011. “WTO Members Drop Food Security Proposals for Ministerial,' \& December - See more at: http://ictsd.org/i/news/bridgesweekly/121019/\#sthash.INqrNjww.dpuf

${ }^{117}$ The scope of issues up for consideration are selected by and agreed to trade ministers prior to the commencement of formal negotiations. Developing countries early on sought to ensure their export trade policies would not be part of the round that is contained in the WTO Doha Declaration outlining the parameters of the current round of multilateral trade negotiations.

${ }^{118}$ The government of Argentina has opposed an expansion of the Doha Round agenda to include disciplines on export restrictions and taxes since 2003. It regards attempts to discipline export restrictions and taxes, especially by the US, EU, Canada, Australia and Brazil - its agri-food rivals - as a strategy to undermine it competitiveness in world food markets. India and Indonesia also have used similar policies and also have been wary of attempts by other WTO member to expand disciplines into this area. However, Indonesia is in favor of the EU proposal. 
${ }^{119}$ The Switzerland-Japan proposal is not yet declassified. A summary of the proposal was obtained by the author from multiple media reports and interviews with trade officials in Geneva in 2008 and 2009.

${ }^{120}$ C. Häberli, "Food Security and WTO Rules," in Food Crises and the WTO, B. Karapinar and C. Häberli (Eds.), (Cambridge: Cambridge University Press 2010) pp. 297-322.

${ }^{121}$ Bridges Weekly, 2011. “Agricultural Export Restrictions Spark Controversy at the WTO” 6 April.

${ }^{122}$ Bridges Trade Weekly, 2011. “Ban Proposed On Export Restrictions That Undermine Food Security” 23 November.

${ }^{123}$ G. Anania, 2013. “Agricultural Export Restrictions and the WTO: What Options do Policymakers have for Promoting Food security?” (Geneva: ICTSD).

${ }^{124}$ See Tussie and Narilkar (2004), note 54.

${ }^{125}$ Authors confidential interviews with WTO delegates, 2008 and 2009. 